\title{
A study on the Theory of Climate Justice in International Environmental Law
}

\author{
Guomin Ding ${ }^{1}$, Guichang Liu $^{1}$, Yunxiang Chen ${ }^{2 *}$ \\ ${ }^{1}$ Law School, Fuzhou University, Fuzhou, Fujian, China \\ ${ }^{2}$ Fuzhou Yaolong Chemical Group Company, Fuqing, Fuzhou, Fujian, China
}

DOI: $10.36348 /$ sijlcj.2020.v03i01.002

| Received: 02.01.2020 | Accepted: 12.01.2020 | Published: 17.01.2020

*Corresponding author: Yunxiang Chen

\section{Abstract}

In recent years, the global environmental problems have become more and more serious, among which the global climate change issue is the most noticeable. As U.S. President Donald Trump announced his withdrawal from the Paris Agreement, the international community has raised new concerns about the sharing of the global environment burden, and the issue of climate justice has attracted more and more attention from the international community. How to deepen the international environmental law principle of "common but differentiated responsibilities" with the relevant ethics of climate justice will be an indispensable theoretical guide for global environmental governance in the future.

Keywords: Climate Justice, Environmental Law, International Community.

Copyright @ 2020: This is an open-access article distributed under the terms of the Creative Commons Attribution license which permits unrestricted use, distribution, and reproduction in any medium for non-commercial use (NonCommercial, or CC-BY-NC) provided the original author and source are credited.

\section{INTRODUCTION}

The issue of global climate change has been paid more and more attention by human beings, and climate issue has long been a difficult problem in the world. How to embody and achieve climate justice on climate issues is of great significance for establishing a good environmental legal system, adjusting environmental legal relations, and effectively and well implementing international environmental law. Due to the unique nature of law, all legislation is a matter of justice, which is all the same in any era or in any country, as well as in international environmental law. Therefore, the realization of international climate justice must be manifested through the fair distribution of environmental issues among countries [1].

\section{The Concept of Justice Value of Environmental Law under the Climate Crisis}

The Concept of Justice Value of Environmental Law In general, the basic idea of environmental law includes, but is not limited to, the concept of sustainable development, the concept of environmental order, the concept of environmental safety and the concept of environmental justice. As a basic value concept of environmental law, environmental justice is the principle of justice to regulate the relationship between man and man and the relationship between man and nature, and always carry out the concept of freedom and equality. This kind of freedom and equality is the freedom and equality of environmental rights and interests among contemporary people, and also the freedom and equality of environmental rights and interests between the present generation and the future generations. Environmental justice provides a way of fair distribution of rights and interests in a country and among countries, and determines the way of division of environmental interests and the appropriate proportion of environmental burden. A society in which environmental benefits and burdens are unequally distributed is clearly an unjust society [2]. As the most basic member of the international community and the most basic subject of international law, it is necessary for countries to bear national environmental responsibility [3].

Environmental fairness means that all subjects are equal in the development, utilization and protection of environmental resources, enjoy the same rights and undertake the same obligations. The environmental rights and interests of any subject are reliably protected, and timely and effective remedies can be obtained when they are infringed upon. Any violation of environmental obligations by any subject should be corrected and punished in a timely and effective manner [4]. In the context of the global climate crisis, climate justice, as a just concept of international environmental law, will certainly be placed in a prominent position by the international community. 


\section{The Development of International Environmental Law under Climate Justice}

Climate justice refers to a set of value systems that treat all entities and individuals fairly throughout the process and in all aspects of climate change. In the sense of value theory, climate justice is a value synthesis. Climate justice shows the axiological significance of justice and the importance of justice as the primary value. The relevant legal achievements in the process of promoting climate justice, including the United Nations Framework Convention on Climate Change and the Kyoto Protocol, etc., have shown that international climate law attaches importance to security, equality and efficiency by pursuing a stable climate regime, taking into account the special needs of economic and social development in developing countries, and setting up flexible market mechanisms [5]. It is entirely possible to establish universal rationality through dialogue and communication [6], as is the real solution to the problem of climate justice.

In the sense of practice theory, climate justice is a kind of value practice. As a value theory, climate justice combines many values, such as equality, security, freedom, efficiency and so on. As a theory, the concept of climate justice comes to an end. It has become the consensus of the international community to reform and innovate the global governance system and establish a new global political theory [7]. However, we should also be aware that, in the negotiation process to deal with climate change, although different parties may reach a consensus on justice in the field of climate change, the cognition of this theory of justice has not been converted into coherent action in the field of climate change. From climate justice in the sense of axiology to climate justice in the sense of methodology, what can be seen is only the justice in the concept. What is needed to deal with climate change is the justice of action [8].

\section{The Basic Situation of International Climate Justice}

\section{Failure of Some Developed Countries to Fulfill Their International Environmental Responsibilities}

On 1 June 2017, amid international consternation and disappointment, U.S. President Donald Trump, in keeping with his so-called campaign "promise", explicitly announced his withdrawal from the Paris Agreement, raising widespread concerns around the world about the "Paris climate process" initiated by the Paris Agreement. What needs further questioning is why the Trump administration withdrew from the Paris Agreement despite widespread criticism both at home and abroad. What will be the impact of the withdrawal of the United States from the Paris Agreement on the Agreement and even on global climate governance [9]?

The declaration of U.S. withdrawal from the Paris Agreement and a series of Trump's "de-climate" policies have triggered a strong response from the international community, which has had a profound impact on the process of global climate governance and brought great uncertainty to global climate governance [10]. Some scholars are pessimistic about the U.S. withdrawal from the Paris agreement, arguing that there will be a large gap in climate assistance promised by developed countries to developing countries, making the implementation of Paris Agreement even less promising [11], and that the agreement's $2^{\circ} \mathrm{C}$ temperature control target cannot be achieved [12] and will inevitably have a negative impact on global climate governance, which will lead to the global climate governance at a low ebb and ultimately a negative international cooperation process on global climate governance [13].

For the purpose of the Paris Agreement, although the decision to withdraw from the Paris Agreement was taken by the Federal Government of the United States, according to article 28 of the Paris Agreement, the parties to the Paris Agreement may apply for withdrawal only 3 years after its entry into force and shall enter into force upon the expiration of one year from the date of receipt of the notification of withdrawal, that is, the final withdrawal of the United States will not enter into force until November 2020. Of course, such an act will inevitably overshadow the "Paris climate process" that the international community is trying to advance. Although the United States is the second largest emitter of greenhouse gases in the world at present, it is still the world's largest emitter in terms of historical accumulation [14]. It is in a leading position in the world in terms of economic status, military strength, technical and financial advantages. The most immediate effect of U.S. withdrawal from the Paris Agreement is the increase of the global funding gap for climate change, while the indirect effect is the hesitation of the world's international political will to tackle climate change and the delay of global innovation in low-carbon technologies. It should be said that this worry of U.S. inaction is not unnecessary. Due to the high per capita carbon emission and the large economy of the United States, its emission reduction actions will directly affect the realization of the "Paris goal". So arguably, the Trump administration's announced withdrawal from the Paris Agreement is a major event in global climate governance. The withdrawal of the United States from the Paris Agreement will have some adverse effects on the implementation prospects of the agreement, which will worsen the leadership of the implementation of the Paris Agreement, increase the funding gap of international climate governance, and weaken the ability of developing countries to cope with climate change. The most direct impact of the U.S. withdrawal from the Paris Agreement is that it will reduce international climate aid funds, seize carbon emission space of other countries, increase carbon emission cost of other countries, weaken the governance capacity of 
climate change of other countries, and increase the difficulty of achieving the goal of temperature rise control of $2{ }^{\circ} \mathrm{C}$. For a long time, the United States has provided the largest amount of international climate funds among the contracting states of the United Nations Framework Convention on Climate Change. Trump administration's withdrawal from the Paris Agreement means that the United States will stop financing international climate change projects, which will inevitably lead to a more serious global climate funding gap [15].

\section{Being Free-Riders}

The U.S. withdrawal from the Paris Agreement poses a great challenge to global climate governance, which will also cause adverse demonstration effects [9]. It would harm the universality of the Paris Agreement and undermine the authority of the negotiations on its implementation. As a developed country, America's delay in action to reduce emissions is bound to have a negative impact on global greenhouse gas emissions, and others are likely to follow suit by delaying action to reduce emissions or reduce research and development of renewable energy. In environmental governance, "being free-riders" seems to be a widespread phenomenon, and other countries may follow America's "inaction" or openly or covertly fail to deliver on their Intended Nationally Determined Contributions (INDCs). The confidence of international climate cooperation will also be weakened, which will partly offset the efforts of global climate governance and weaken the influence of multilateral platforms on climate issues. Therefore, the negative impact on the Trump administration's withdrawal from the Paris Agreement cannot be underestimated [9].

If the phenomenon of "being free-riders" is widespread, it is bound to reduce the confidence of international climate governance cooperation, undermine the foundation of international climate governance regime and delay the process of global climate governance. Unlike the enforcement mechanisms of domestic laws, the implementation of international treaties largely depends on the leadership of major Powers, especially for the Paris Agreement which adopts an INDC emission reduction model and has weak binding force. The collective leadership demonstrated by China, the United States and Europe at the negotiating stage of the Paris Agreement has strongly contributed to the conclusion of the agreement, and the strong leadership and exemplary role of the major Powers are still indispensable in the implementation stage. At present, the international climate governance regime is constructed at the core of the Paris Agreement, and the effectiveness of global climate governance depends on the legitimacy of the Paris Agreement, which is rooted in its universality. Universality was seen as the highlight of the Paris Agreement [16], attracting the participation of almost all countries and requiring developed countries to assume quantitative emission reduction responsibilities that differed from those of developing countries, which was also a major aspect of the Paris Agreement distinct from the Kyoto Protocol. As the world's largest economy, the absence of the United States from the implementation of the Kyoto Protocol ultimately made the implementation of Kyoto not very effective [17]. Now the withdrawal of the United States from the Paris Agreement will inevitably harm its universality, even somewhat undermine the foundations of global climate governance, and ultimately lead to the adverse impact of "free riding" in environmental governance in more and more countries led by the United States [9].

\section{The Path to the Fair Distribution of Environmental Responsibilities under Global Climate Justice}

\section{Deepening the Principle of Common but Differentiated Responsibilities through Climate Justice}

The principle of "common but differentiated responsibilities" is one of the basic principles for the world to assume environmental responsibilities, and it also reflects the values of international environmental responsibilities -- to seek justice. In the process of assuming international environmental responsibilities, all countries should, in accordance with the requirements of the unity of facts and values, the unity of responsibilities and obligations, and the unity of interests and rights, dare to assume responsibilities and protect the environment to the maximum extent possible on the premise of striving for justice [15].

In his Theory of Justice, Rawls points out that justice is the primary value of the social system, just as truth is the primary value of the ideal system. A theory, however delicate and indirect, must be rejected or amended as long as it is not true; likewise, certain laws and systems, no matter how efficient and organized they are, must be reformed or repealed as long as they are unjust. As the primary value of human activity, truth and justice are uncompromising [18].

The moral basis of global climate justice is in fact the equality between nations and between people. In the existing international community, the guarantee of the equal right of every person to survival and development is first and foremost the guarantee of the equal right of every nation to survival and development. Those who oppose the principle of "common but differentiated responsibilities "on climate issues has the problem of not basing their theory on the basic premise of global equality. In other words, they essentially deny "equal human rights" and then further deny "national equality". Global climate justice based on egalitarianism is a justice requirement that can be justified morally. Only by establishing global climate cooperation on the basis of egalitarianism, and only by forming a moral community of universal equality and 
respect, can mankind jointly respond to the growing climate crisis [2].

\section{Equitable Distribution of Contemporary International Environmental Responsibilities under the Guidance of Philosophy of Environmental Law}

Human life and its cultural heritage need a stable living environment. The frequent climate disasters caused by climate change have disturbed the normal living arrangements of human society. Since the 1950s, with the complete end of the world war, people's demands for a natural environment suitable for human survival and development have become more and more intense, and they have a higher level of pursuit for a stable and comfortable social life. In this context, for the better survival and development of mankind, the international community actively responds to the rapidly deteriorating global climate and seeks to reverse the adverse situation of climate change. Since addressing global climate change involves not only equity and justice in the international legal system, but also the value judgment of human rights protection and ethics, the original purely technical issue has evolved into a cross-disciplinary issue involving jurisprudence, ethics and so on [8].

How climate change arises and how it acts and affects is a scientific issue. However, who should be responsible for climate change, how to be responsible and to whom should be responsible are ethical and value issues. The core of ethical and value issues are justice and the response to climate change cannot bypass the dimension of justice [19].

To date, the international community's answers to these questions lack the answers that will be unanimously endorsed by all nations and the just arrangements that will be acceptable to all nations [8]. From the perspective of environmental ethics, it must rise to the height of the philosophy of international environmental law, analyze the deadlock of climate justice, and try to find a way to solve the deadlock of climate justice.

\section{CONCLUSION}

Justice is the primary evaluation criterion of social system legitimacy. In the modern social system, whether it is political system, economic system or other systems, the core and main part of it is the expression of legitimacy through the legal system without exception. And when we combine the concept of "justice" with a particular legal field, it means that we use the primary criterion of "justice" as a critical or constructive tool to prove or disprove the legal system in this field. The concept of "climate justice" came into being in the context of climate change and the increasingly urgent need of human response, and the need for concrete, clear and institutionalized responsibilities. Climate justice has different characteristics from other fields of justice, and it has important practical value in international climate negotiation and domestic legislation to deal with climate change. To understand the principles of climate justice is the work that all countries in the world have to do to carry out international cooperation and formulate domestic policies and legislation to deal with climate change.

\section{REFERENCES}

1. Gong, Y. (2006). Justice in environmental law. Forum on political and Law, 06 (05): 92-97.

2. Chen, Q. (2012). Philosophy of Environmental Law. Beijing: China legal Publishing House.

3. Bao, Y. (2008). National Responsibility in International Environmental Protection. Today's Southern China (Theoretical Innovation Edition), 08(09): 151-153.

4. Chen, J. (2012). What do We Owe Each Other: on Global Climate Justice. Philosophical Studies, 12(07): 78-85.

5. Wang, C. (2013). On Climate Justice. International Journal of Social Sciences (Chinese Edition), 13, 30(02): 30-44+5-6+10.

6. Liu, X. (2004). On the International Environmental Responsibility of States. Hunan Social Sciences, 04(01): 76-78.

7. Yu, X. (2018). Global Common Governance Theory and Chinese Practice. Journal of Social Sciences of Jilin University, 18, 58(06):71-82+204205.

8. Wang, J. (2011). The Climate Justice Impasse and Ways Forward: Considerations across the Disciplines of Philosophy of Law and Economics. Contemporary Asia Pacific, 11(03):80-95+79.

9. Luo, L. (2018). The influence of the Withdrawal of the United States from the Paris Agreement and the Study of China's Response. Jiangsu Social Sciences, 18(05):184-193+275.

10. Li, H. (2018). Climate Policy Analysis of the European Union in the Context of the Trump Administration's "Declimate" Campaign. European Studies, 18, 36(05):43-60+6.

11. Haas, P. M. (2017). Parxit, the United States, and the World, Chinese Journal of Population, Resources and Environment, 17(3).

12. Sanderson, B. (2017). Delays in US Mitigation Could Rule out Paris Targets, Nature Climate Change, 17(7).

13. Stavins, N. R. (2017). Why Trump Pulled the U.S. out of the Paris Accord and What the Consequences Will be. https://www. foreignaffairs.com/articles/2017-12-05.

14. Quéré, L. (2016). Global Carbon Budget 2016. Earth System Science Data.

15. Li, M. (2008). Justice is the Inevitable Choice to Assume International Environmental Responsibility. Journal of the Party School of the Shanxi Provincial Party Committee of the Communist Party of China, 08 (02): 98.

16. Rosenzweig, H. R. (2016). Global Climate Change Policy and Carbon Markets: Transition to a New 
Era, London: Macmillan Publishers Ltd.

17. IPCC. (2014). Climate Change 2014: Mitigation of Climate Change, Cambridge: Cambridge University Press.

18. Yan, G. (2010). On Climate Justice-also on International Environmental Justice and Fairness and Sustainable Development. Business Culture (Academic Edition), 10(08):23-24.

19. Peng, B. (2014). Climate Justice is the basis of Climate Governance. Journal of Jishou University (Social Science Edition), 14, 35(04):28-33. 